\title{
MOBILITY AND WORKING OPPORTUNITIES IN THE EU AND SLOVAKIA*
}

\author{
Lubica Bajziková** \\ Peter Bajzík $k^{* * *}$
}

Received: 1. 9. 2019

Preliminary communication

Accepted: 12. 5. 2020

UDC 005.966.3(439.22)

DOI https://doi.org/10.30924/mjcmi.25.1.6

$331.55(4-6 \mathrm{EU})$

\begin{abstract}
Current globalisation processes witness the mobility and migration of labour as their characteristic features. The free movement of people and workers is one of the rights of $\mathrm{ci}$ tizens of the European Union (EU), and includes the right to move, to reside and to work in an EU member state without discrimination. The aim of this paper is to analyse the labour mobility within the EU with special attention to Slovakia. In its historical development, Slovakia belonged to countries with population migrating predominantly to foreign countries and was not a traditional destination country for migrants. However, today it has gradually become a state that employs foreign labour, especially in production plants. This change has not only been contributed to by Slovakia's accession to the EU, but especially by the economic development of the state and the creation of new job opportunities for both domestic and foreign labour. The study analyses the intra-mobility in Slovakia and focuses on analysis of the trends in employment of foreign workers from $E U$ and non-EU member states between 2007 and 2019. For the purposes of this paper, data were extracted from a relatively large number of prominent sources, for example: the European Commission, Eurostat, and the International Labour Organization (ILO)
\end{abstract}

reports, and the Slovak Statistical Office resources related to labour mobility. In the desk research, the collected information were analysed and subjected to critical multidimensional assessment from quantitative, absolute, and relative, as well as cross-sectional perspectives. Special attention was paid to analysis of documentation that accompanied these data. The significance of the examined topic is underlined by the fact that Slovakia is currently a recipient of foreign labour due to insufficient qualification of domestic labour. It therefore introduces new legislative measures to speed up the employment process, remove administrative barriers and, in cooperation with employers, accelerate the process of adaptation to new work-related conditions, especially for workers from non-EU countries. In addition, employment of third-country nationals in Slovakia is a relatively demanding and lengthy process. On the one hand, the employment of foreigners contributes to economic development. On the other hand, this process stirs various problems, which are mainly related to cultural and social integration, and the removal of which cannot be achieved only through the legal regulations.

Keywords: labour mobility, migration, employment, European Union, labour market, Slovakia

\footnotetext{
* This work was supported by the Slovak Research and Development Agency under the contract No. APVV-160091. A previous version of this paper has been presented and discussed at the 13th International Conference "Challenges of Europe: Growth, Competitiveness, Innovation and Well-Being", organized by Faculty of Economics, Business and Tourism Split, in May 2019. Management - Journal of Contemporary Management Issues is one of the supporting journals of the Conference. All the papers have been reviewed and revised, according to the standards of this Journal.

** Lubica Bajzíková, PhD, Professor, Faculty of Management, Comenius University in Bratislava, E-mail: lubica. bajzikova@fm.uniba.sk

*** Peter Bajzik, PhD, Faculty of Management, Comenius University in Bratislava, E-mail: peter.bajzik@fm.uniba.sk
} 


\section{Journal of Contemporary Management Issues}

\section{INTRODUCTION}

Mobility is one of the most important discussion topics in the EU. Labour mobility has an impact not only on the population, but also on social and economic development, political stability, and security of European countries. Europe has low mobility, affecting only about $4 \%$ of citizens of working age (20-64 years), although with large differences across countries. The Maastricht Treaty has defined the right to work and reside for foreign employees in any EU countries under the same conditions as domestic employees. The Treaty also guarantees equal treatment related to working opportunities, social services and benefits, tax, trade union membership, access to education, apprenticeship, and vocational training (European Commission, 2015). Mobility has an economic benefit in receiving countries, with mobile workers contributing to GDP growth in their host nations.

\section{LABOUR MARKET SITUATION}

Labour mobility can be explained by the 'push and pull' model, which has a significant impact on migration (Borjas, 2014). The push factors create conditions that press individuals to move out of the country of origin. The pull factors are conditions that entice people to come, work and reside in a country of destination. People move, if they believe that their life situation can be improved, e.g. that the benefits of moving surpass benefits of staying (Ritzen, 2017). Pull factor examples include increased income, achievement of a better career, and higher quality of life, education level, better social services, security and the like.

Based on Palmer and Pytlíkova (2015), push factors can be considered as threats to life, meaning natural disasters, civil, ethical, or other unrest or war. One of the main forces of EU mobility are labour market opportunities. Migration is expected to increase when unemployment rises. Also, the differences of income may have a similar effect: larger income gap causes higher mobility and vice versa. Kahanec and Zimmermann (2016) stress that mobility is more oriented to countries, where GDP per capita is higher, which sets the course of the migration flows.

One-way mobility from South to North and from East to West of the EU is gradually declining, and the countries are not categorised into emigration ones anymore. Neither the mobility, nor migration stream from peripheries to centres only, but simultaneously they move in the opposite direction, as well, being influenced by the development of international investment relations. Moreover, the topicality of the phenomenon has stemmed from its dynamic and quantitative development in recent years. The number of migrating workers and students has been growing, and, in addition to the traditional target regions, new destinations have appeared. Nationals of one country, moving to another one do not represent solely an economic problem, since it can be viewed from historical, demographic, geographical, or social perspectives, as well. The problems of high unemployment in the EU can be reduced and eliminated by promoting employee mobility and introducing some market regulations (Boeri and Garibaldi, 2009).

Labour mobility increases demands for a more adaptable workforce, through flexible working contracts with more temporary jobs and more job changes. Labour mobility is considered as one of the important factors, affecting the equilibrium in the labour market. The mobility of workers and jobs may create a better match between 
supply and demand in the labour market, with increased competitiveness of workers, improving their employment status and job position. Research shows that with the mobility of workers, their flexibility can be increased, which allows better resilience to sudden economic shocks (Pissarides and Wadsworth, 1989; Brezzi and Paincentini, 2010; Blanchard and Katz, 1992; Partridge and Rickman, 2003, 2006; Mitze et al., 2012). The mobility of labour from low to high income per capita regions can contribute to even the income levels across regions.

Ideally, a labour market would reach the balance among workers and employers. Unemployment is the result of imperfection in the demand and supply of the workforce. It can be caused by various reasons, such as ageing population, lack of proper labour qualification, and regional disparities. The rate of unemployment in the EU was $6.2 \%$ in December 2019, which was the lowest rate recorded among the EU28 since October 2008 (European Commission, 2020).

Among the member states, the lowest unemployment rates in December 2019 were recorded in the Czech Republic (2\%), Netherlands and Germany (both 3.2\%), and Poland (3.3\%). The highest unemployment rates were observed in Greece (16.6\%) and Spain (13.7\%) (European Commission, 2020).

\section{ECONOMIC AND SOCIAL EFFECTS OF LABOUR MOBILITY}

The European Commission found in 2008 that mobility of labour force had an approximate impact of $21 \%$ on GDP growth in the EU between 2000 and 2005. The accession of 10 new states to EU in 2004 has shown that labour mobility has contributed around 2\% to GDP growth (which amounted to 214 billion EUR). In addition to GDP, this trend also affects other economic indicators, such as economic growth, unemployment, poverty, income distribution, etc (Baas, Brucker and Hauptmann, 2010).

From the economic point of view, the mobility of employees promotes labour market efficiency, by better coordination of the available labour supply with employers' demand. Relations between social groups may change, due to the social impact of occupational mobility. Migrants, as a part of minority groups in the receiving country, may cause tensions with the local majority (Favell and Recchi 2009).

\section{AIMS AND METHODOLOGY}

The aim of the paper is to examine labour mobility within the EU and to discuss the current state of mobility and working opportunities in Slovakia. For the purpose of this study, data were extracted from a relatively large number of prominent sources, such as the European Commission's reports, Eurostat, ILO, the Slovak Statistical Office, and other resources related to labour mobility. The accumulated information were analysed and subjected to critical multidimensional assessment from quantitative, absolute, relative, and cross-sectional perspectives. Special attention was paid to relevant statistical data analysis and textual analysis of documentation, accompanying the data. Thus, standard secondary research is used, with an emphasis on a thorough analysis of statistical data, supporting documents and prior research results. The paper focuses on systematic overview analysis and summation of data from external resources, i.e. reports, guidelines and statistical data of government institutions. 


\section{Journal of Contemporary Management Issues}

\section{MOBILITY WITHIN THE EU (INTRA MOBILITY)}

The Europe 2020 strategy aims to support and facilitate intra-EU mobility, and to better match labour supply with labour demand. Its other goals include creating conditions to attract and retain talented workers from EU.

Based on literature and statistical data, we can identify two forms of workforce mobility in the EU:

- Intra-EU mobility represents the movement of EU nationals. This represents both mobility within and between EU member states.

- Migration is mobility of nationals between states on a permanent or semipermanent basis.

Changes in transport, communication, and technology help to speed up and simplify migration, yet the United Nations (UN) estimates that only $3.5 \%$ of the world population are international migrants (approximately 272 million people in 2019). Most international migrants also move between countries located within the same region.

According to the European Commission data, in 2020 about 12.9 million people (approximately $4.1 \%$ of the EU active labour force) in the age group 20-64 had moved within the EU and lived in another member state. Each day, 1.5 million people also commute to another EU member state as cross-border workers (European Commission, 2020).

Intra-labour mobility in the age group 20-64 exists in three forms: long-term mobility, cross-border mobility and posting workers:

- Long-term labour mobility means that a person moves residence to another member state of which he/she is not a citizen, for a period of at least one year, to take up work, or to find work (EC, Directive 38, 2004).

- Cross-border mobility refers to a person, who is a resident in one country and is employed in another one, and regularly crosses borders for the purpose of work (EC, Directive 38, 2004).

- Posting workers are employees, who are regularly sent by their employers to another member state on a temporary basis (European Commission, Directive 38, 2004).

It is not always possible to identify the differences between these forms of mobility and to numerically express how they overlap. For example, in some EU countries, long-term mobility workers can be counted as both cross-border, as well as posting workers. Furthermore, the number of people within the long-term mobility group can also include those who live in a different EU member state than their citizenship, and work in another EU country: e.g. a Slovak residing in Hungary and working in Austria. Furthermore, posted workers can be counted as a foreign workforce, if they referred to 'state of residence' and 'country of origin' differently (European Commission, 2020).

\section{LEGISLATION AND ECONOMIC INSTRUMENTS TO SUPPORT EMPLOYMENT AND MOBILITY IN SLOVAKIA}

The rights and obligations of the employer and employee are regulated by the Labour Code and apply to the employment of Slovak citizens, as well as to the employment of foreigners. The Slovak legal system 
does not define the term migrant. However, the term 'foreigner' is used. A foreigner is anyone who is not a citizen of the Slovak Republic, or a stateless person (Act No. 404/2011 Coll. on Residence). However, in EU context, a foreigner is a person, who is not a citizen of an EU member state. The term 'migrant' is broad, and it is not always clear to whom it refers. It may concern voluntary migration within the country (domestic migration), or voluntary migration from one country to another (international or cross-border migration).

For the employment of the foreigners in Slovakia, it is also necessary to respect the special conditions of employment, regulated by Act. No. 5/2004 Coll. on Employment Services.

There are two main types of internal labour mobility in Slovakia - internal migration and commuting. Migration within the country means a change in the residence of a mover. Commuting is based on a rule that the place of residence does not change (i.e. a worker's place of work and place of residence are situated in two different locations). Comparing these two types, commuting is more widespread, with approximately 140,000 people commuting (5\% of those employed). But based on cross-country comparisons, we can observe that mobility flows inside Slovakia are low in international terms (Vagac, 2013).

In 2015, the Slovak government adopted the Employment Service Act, supporting mobility for work by offering various allowances, such as monthly payments for jobseekers during the first six months, if a change of permanent residence is required. There are three types of financial allowances: commuting allowance, moving allowance and transport subsidy. These should help to decrease the costs of mobility for unemployed persons. Applicants must be registered in the employment database for at least three months. The amount of the allowances should cover the cost of relocation and motivate the jobseekers to move, as to find a job in any region of Slovakia (UPSVR, 2020). Housing expenses, related to the change of residence, are the basis for providing the allowance to pay for rentals. The monthly contribution accounts for $80 \%$ of the costs of housing. The maximum amount ranges from $400 €$ to $600 €$, if both spouses meet the conditions for the grant.

In addition, some measures have been taken to support investments, social housing and infrastructure development, with the aim to reduce regional disparities and stimulate intra-mobility, especially for the unemployed persons searching for jobs more than $70 \mathrm{~km}$ from their home. However, intra-mobility of labour is very low and reflects the level of regional differences in unemployment rate, as well as the lack of job opportunities.

Labour mobility in Slovakia mostly goes from East to West, mainly due to the insufficient job opportunities in the East. Most of the production plants and industrial areas are in the Western part of the country. The Bratislava region is the most attractive migration area, with many job opportunities. Many migrants, who move to suburban districts commute back to the city for work. Compared to many EU countries, there is a low tendency toward mobility, not only because of family ties, but also because of high costs of housing and rent. Up to two-thirds of the unemployed people are not willing to travel more than one hour daily to their workplace and do not want to spend more than $50 €$ on travel (Trend, 2018). The unequal development of the Slovak regions causes significant differences in the unemployment rate between East and West. In December 2019, the highest recorded 


\section{Journal of Contemporary Management Issues}

unemployment rate was $8.54 \%$ in the Presov region, followed by Kosice $(7.57 \%)$, Banska Bystrica (6,69\%), Zilina (3.96\%), Trencin $(3.2 \%)$, Nitra $(2.93 \%)$, Bratislava $(2.83 \%)$ and Trnava (2.63\%). The average unemployment rate in Slovakia was $4.92 \%$ and long-term unemployment equalled $3.5 \%$ in January 2019. In Eastern Slovakia, 14.2\% people were recorded as having moved away from the Presov region, because of the lack of job opportunities, low levels of transport infrastructure and the low competitiveness of the region (UPSVR, 2020).

Despite Slovakia being a relatively small country, we can observe large regional disparities in dimensions of economic and social conditions, such as GDP per capita, labour productivity, real wage, unemployment rate, infrastructure, etc. For analysis of migration flows, one must also consider the ability and willingness of the population to migrate for work. Compared to other EU member states, Slovakia is one of the countries with the lowest willingness of the inhabitants to migrate for work. This is partly due to historical reasons, stemming from the political transformation of 1989 and strong relationships to acquired property. The privatisation of co-operative and municipal dwellings at the beginning of the 1990s increased the rate of home ownership to $90 \%$. It is evident that a high proportion of home ownership has a negative impact on labour mobility (Oswald and Blanchflower, 2013). In Slovakia, the rental market is very limited, and only a small percentage of social housing is provided by municipalities.

\subsection{Factors of internal labour mobility in Slovakia}

Based on the analysed statistical data, there are two groups of factors that influence internal labour mobility in Slovakia: economic and social. The economic factors are (Vagac, 2013):
- regional labour market conditions, including the level of wages, regional employment rate and employment opportunities, different GDP per capita

- housing market conditions and housing policy, with employment opportunities usually concentrated in prosperous regions affordable housing can be considered as a barrier for many potential workers from less developed regions

- transportation, improving the infrastructure can be beneficial for a commuting labour force, as transportation costs and connections play a significant role in commuting decisions

- international migration, may substitute internal migration due to stronger economic or other incentives

- government policy, such as state aid schemes, and infrastructure, education, and active labour market policies.

Social factors are related to the following (Vagac, 2013):

- demographic characteristics, including age, gender, marital status, have an impact on the workforce mobility

- education, economic status, and skills, influence the probability of moving, with insufficient education and inadequate skills likely to become barrier to mobility from regions with high unemployment rates

- cultural and other factors, including attitudes related to the place of residence, such as community, family, and personal relationships, impact on a person's willingness to move for work.

\subsection{Employment of foreigners in Slovakia}

The impact of foreigners on an economy is a much-discussed issue. Historically, Slovakia was not considered as a host 
country for migrants. It is a culturally homogenous country, which has not been affected by the dramatic increase of migration, either during 20th century, or by the migration crisis since 2015. However, significant changes can be observed in migration. following the accession of Slovakia to the EU. Since 2004, legal migration into the nation has increased four-fold, and the increase in the foreign population between 2004 and 2008 was the second highest among EU member states. Nevertheless, the amount of foreign nationals in the total population remains low. In December 2019, foreign nationals amounted to $2.6 \%$ of the total population (143,000 people). The most significant reason of legal migration or mobility to Slovakia are work, business and studies. The Slovak legal system creates suitable conditions for employment of foreigners - from both EU member states and non-EU countries, while their right of family integration is additionally respected by Act No. 404/2011 Coll. on residence and Act No. 480/2002 Coll. on asylum policy. In Slovakia, equal conditions are created for both domestic and foreign citizens to choose and carry out their employment.

The status of foreign nationals in employment relations in Slovakia can be briefly described as follows:

- Foreigners are protected by the Slovak Labour Code;
- Provisions relating to the compulsory health insurance apply to all employees;

- The provisions of the Social Insurance Act include payment of social insurance, compensation due to inability to work, maternity benefits, and pension insurance.

Since May 1, 2018, new amendments to the Labour Code mean that a company cannot employ a foreigner, if it is registered as an illegal employer. To employ foreigners, the following conditions must be met: the number of employed foreigners cannot exceed $30 \%$ of the total number of employees and the unemployment rate in the region in question must be lower than $5 \%$.

Slovakia is changing from a migrant state to a state that attracts foreign workforce. The foreigners in Slovakia are mostly coming from neighbouring countries (Austria, Czech Republic, Hungary, Poland, and Ukraine) and reach approximately $43 \%$ of the total foreign population in Slovakia. Citizens from Romania, Bulgaria, Serbia, and Ukraine represent about $23 \%$ of all migrants to Slovakia (Ministry of Interior Affairs of the Slovak Republic, 2020). The number of foreign employees in Slovakia reached 60,692 persons $(2.2 \%$ of active workforce) in December 2019 (see Table 1).

Table 1: Top seven EU Member and non-EU Member States (number of foreign employees, December 2019)

\begin{tabular}{llll}
\hline EU member states & Number of persons & Non-EU member states & Number of persons \\
\hline Romania & 8,664 & Ukraine & 16,998 \\
Czech Rep. & 5,979 & Serbia & 5,837 \\
Hungary & 5,502 & Vietnam & 1,128 \\
Poland & 2,539 & Georgia & 622 \\
Bulgaria & 2,300 & Bosnia and Herzegovina & 618 \\
Italy & 1,264 & Macedonia & 537 \\
Croatia & 1,142 & Georgia & 519 \\
\hline All EU states total & $\mathbf{3 2 , 1 1 4}$ & All non-EU states total & $\mathbf{2 8 , 5 7 8}$ \\
\hline
\end{tabular}

Source: UPSVR. www.upsvr.sk, December 2019; data processed by authors 


\section{Journal of Contemporary Management Issues}

The lack of qualified labour is beginning to pose a serious threat to further economic development of Slovakia. The Slovak Labour Office registers approximately 180,000 unemployed persons, but routinely has more than 100,000 vacancies. This paradox partly stems from the fact that new jobs open due to increased production in Slovakia's large automotive industry, but qualified labour is not available in the local market. The consequences of such structural discrepancy between supply and demand in the labour market are weak utilisation of economic potential of domestic population, low confidence in the education system, limited development of enterprises, and low productivity growth.

New regulations have been applied to encourage employment of foreigners from non-EU member states to fill the vacancies. The main objective is to create equal working conditions with local labour, to remove barriers and administrative obstacles, eliminate social dumping (labour with wages and benefits that do not meet the set standard in a country), and guarantee equal treatment, pay, as well as welfare benefits and social system.

Trelova (2017) points out that Slovak companies began to face a lack of qualified workforce, and one of the fastest and most effective measures implemented to tackle the problem was employment of skilled and educated migrant workers and foreign students. She adds: "The employers are increasingly interested in foreign employees and are looking for people in the neighbouring countries. It is not interest only in foreign workers from other European countries, but people from countries outside the European Union also find their employment on the Slovak labour market. These are especially migrants who obtain a work permit in Slovakia."
In 2018, Business Alliance of Slovakia, in cooperation with the Institute for Economic and Social Reforms (INEKO), conducted a survey on the employment of foreigners from non-EU member states. Companies participating in the survey belonged to the following sectors: $36 \%$ from industry, $22 \%$ from services, $15 \%$ from construction, $13 \%$ from agriculture, $11 \%$ from trade and 3\% from energy or waste processing. Half of the firms surveyed had been actively looking for workers abroad to fill the gap between the shortage of domestic workers and the company needs. Furthermore, the majority of employers $(58 \%)$ were satisfied with the performance of foreigners, while only 4\% expressed dissatisfaction. The survey revealed that foreigners earned either less $(50 \%)$ or the same $(47 \%)$, compared to Slovak nationals. According to employers, foreigners were more flexible (52\%), willing to work harder (39\%), and work longer (24\%) compared to Slovak nationals. Slovak companies recruited foreigners mostly directly from the labour market $(65 \%)$, rather than via personnel agencies (35\%) (Business Alliance of Slovakia, 2018).

Based on statistical data, the occupations of foreigners working in Slovakia are as follows: machine operators, fitters of machinery and equipment (25,923 persons), qualified workers and craftsmen $(8,785$ persons), and unqualified workers $(7,346$ persons). In terms of economic sectors, the highest proportion of foreigners can be found in engineering, manufacturing, and the automotive industry. In terms of geographical distribution, most foreigners work in the Bratislava region $(23,800)$ and in the Trnava region $(7,100)$, with foreign workers accounting for $8.2 \%$ of total workers in Slovakia (UPSVR, 2020). 


\subsection{Short-term work migration from Slovakia}

The number of Slovak nationals, working outside of their country for a minimum of one year, including cross-border commuters, reached 142,000 in 2019 (about $5.6 \%$ of the total employed population). The largest group of working abroad is from the Presov region (21.3\%), which, unsurprisingly, has the highest unemployment rate $(8.54 \%)$ in Slovakia. Short-term migration is the only type on which reliable data exists, with data on other types of mobility being only estimated. The Slovak Statistical Office estimates that there may be 300,000 350,000 people from Slovakia working and living abroad (Slovak Statistical Office, 2020). However, these data are not necessarily accurate, due to difficulties with obtaining and processing the data, including freedom of movement in the EU requiring no registration.
Today, the average Slovak migrant is older than 35 years, with secondary education, without family ties, tolerant to risks, and works in construction, or industry. Entry to the EU labour market has made it easier to seek jobs, in which limited language skills are sufficient. In 1Q 2019, some 124,600 people from Slovakia were short-term migrants, with a breakdown in age groups as follows: $15-24$ years, 10,700 ; $25-34$ years, 34,400 ; $35-44$ years, 34,500 ; 45-54 years, 30,800; 55 and above, 16,100 . Most had either secondary vocational education without graduation $(42,200)$, or secondary education with graduation $(61,700)$. They worked in the following sectors: industry (32,600, of which 27,200 were men and 5,400 women); construction $(30,900$, of which 30,500 were men and 400 women); healthcare and social work $(22,600$, of which 2,100 were men and 20,500 women) (The Slovak Statistical Office, 2020).

Table 2: Selected states with the most short-term work migrants from Slovakia 1Q 2019 (in 000)

\begin{tabular}{lrrc}
\hline Country & Total & Men & Women \\
\hline Czech Republic & 29.4 & 24.7 & 4.7 \\
United Kingdom & 3.6 & 3.6 & - \\
Austria & 40.5 & 17.4 & 23.1 \\
Germany & 23.9 & 20.6 & 3.3 \\
Italy & 1.6 & 1.4 & 0.2 \\
\hline
\end{tabular}

Source: Slovak Statistical Office, www.statistics.sk, 1Q 2019.

Workers from Slovakia mostly found job opportunities in the Czech Republic and Austria, which together amount to almost 70,000 (see Table 2). It is interesting to note that there are less Slovak workers in the Czech Republic, than in Austria. This is surprising, considering the language and cultural bonds between Slovaks and Czechs, and their periods of common citizenship in the past. A relatively high number of Slovak women work in Austria as nurses and in health care services. Germany is the country with the third highest number of Slovak workers $(23,900)$. 
Journal of Contemporary Management Issues

Table 3: The number of short-term workers, migrating from Slovakia to EU between 2007-1Q 2019 (in 000)

\begin{tabular}{llllllll}
\hline Year & 2008 & 2009 & 2012 & 2014 & 2017 & 2018 & $2019(1 \mathrm{Q})$ \\
\hline Total & 175.5 & 128.8 & 113.7 & 130.5 & 155.2 & 142 & 126.4 \\
Czech Rep. & 73.9 & 55.1 & 42.7 & 37.2 & 39.1 & 32.3 & 29.4 \\
UK & 23.2 & 13.0 & 6.9 & 9.0 & 6.2 & 4.3 & 3.6 \\
Hungary & 21.5 & 13.5 & 7.8 & 5.0 & 9.1 & 6.7 & 8.6 \\
Austria & 17.2 & 16.5 & 27.1 & 38.7 & 52.4 & 56.5 & 40.5 \\
Ireland & 8.8 & 4.6 & 0.6 & 1.3 & 0.6 & 0.3 & 0.3 \\
Germany & 8.8 & 8.1 & 7.9 & 16.3 & 24.5 & 23.9 & 23.9 \\
Italy & 8.6 & 5.7 & 3.7 & 3.6 & 3.7 & 2.3 & 1.6 \\
Netherlands & 2.9 & 2.8 & 6.9 & 6.0 & 6.7 & 3.2 & 4.7 \\
Others & 11.8 & 9.7 & 10.2 & 13.4 & 12.9 & 12.6 & 13.7 \\
\hline
\end{tabular}

Source: Slovak Statistical Office, www.statistics.sk, December 2019, data processed by authors

It is evident that the overall number of short-term migrants from Slovakia between 2008 and the first quarter of 2019 was changing - with a substantial overall decline from 175,500 to 126,400 . The number of migrants declined to its lowest during the economic crisis from 2008-2012, dropping from 175,500 to 113,700 (a decline of $35.21 \%$ ). Although the number of Slovak nationals working abroad increased between 2014 and 2017 (from 130,500 to 155,200 - representing the approximately change of $19 \%$ ), another noticeable decline followed. This is probably due to more vacancies in Slovakia itself, with about 100,000 being available in December 2019. From 2017, the number of short-term workers abroad declined from 155,200 to 124,600 in 1Q 2019. The most recent data clearly shows that the number of short-term Slovak migrants is at its lowest in seven years.

\section{CONCLUSION}

Despite being enshrined in its rules and encouraged in its strategies, labour mobility is not very high within the EU, with only a small part of the population working in another state or being mobile. One of the main forms of motivation for mobility is to find a better job and more adequate work opportunities. However, the EU member states suffer from unemployment, with an average rate of $6.2 \%$. Nevertheless, the increased labour mobility brought on by the accession of new EU member states has contributed around $2 \%$ to GDP growth.

Slovakia historically belonged to the category of countries with a population, migrating predominantly to foreign nations and was not a traditional destination country for migrants. Since accession of Slovakia into the EU, workforce mobility has become easier and has played a significant role in the development of the Slovak economy.

Internal mobility flow in Slovakia has an East to West direction, due to more job opportunities in Western part of the country, and high unemployment in Eastern regions. To increase mobility, several financial incentives have been adopted, such as commuting and moving allowances, and transport subsidies.

Slovakia is becoming more attractive for foreign workers from the EU as well as from non-EU countries. Yet, the percentage of foreigners in the total population remains 
comparably low, with only $2.6 \%$ in 2019 . New procedures and measures have been applied to accelerate the employment of foreigners from non-EU member states. The measures remove barriers and administrative obstacles. Many insufficiently occupied professions are benefiting from foreign labour from countries outside the EU, such as Serbia and Ukraine. The foreign workforce contributes to filling job vacancies in key industries, especially in the automotive sector.

Cross-border and short-term migration are the typical form of mobility, with Slovak workers mostly finding job opportunities in neighbouring states, such as the Czech Republic and Austria. Most men find work in industry and construction, most women in health care and social work.

\section{REFERENCES}

1. Baas, T., Brucker, M. and Hauptmann, A. (2010). Labour Mobility in the Enlarged EU. Bonn: Springer-Verlag Berlin Heildeberg. doi:10.1007/978 -3-642-02242-5.

2. Bajzikova, L., Sajgalikova, H., Polakova, M. and Wojcak, E. (2013b). Dynamika zmien vo vedomostnej spolocnosti vo vybranych sektoroch slovenskej ekonomiky. Bratislava: Ofprint.

3. Blanchard, O., J., Katz L., F., 1992, Regional Evolutions, Brookings Papers on Economic Activity, 23(1), 1-76.

4. Blanchflower, D., G., Oswald, A., J., (2013). Does High Home- Ownership Impair the Labor Market? National Bureau of Economic Research. doi: 10.3386/w19079

5. Boeri, T., Garibaldi, P. (2009). Beyond Eurosclerosis. Economic Policy, 24(59), 409-461.

6. Borjas, J., G., (2014). Immigration Economics. Boston: Harvard University Press.
7. Brezzi, M., Piacentini M. (2010). Labour mobility and development dynamics in OECD regions, OECD Working Paper.

8. Business Alliance of Slovakia. (2018). Nedostatok zamestnatncov riešia podnikatelia aj zamestnávaním cudzincov v SR. https://www.alianciapas. sk/2018/04/27/prieskum-pas-a-ineko-ozamestnavani-cudzincov-v-sr/

9. European Commission (2016). Commission Staff Working Document Country Report for 2016 - Slovakia. http://ec.europa.eu/europe2020/pdf/ csr2016/cr2016_slovakia_sk.pdf.

10. European Commission. (2004). Directive 2004/38/EC of the European Parliament and of the Council of 29 April 2004. https://eur-lex.europa.eu/ LexUriServ/LexUriServ.do?uri=OJ\%3 AL\%3A2004\%3A158\%3A0077\%3A0 $123 \% 3 \mathrm{Aen} \% 3 \mathrm{APDF}$

11. European Commission. (2016). European Semester Thematic Factsheet - Undeclared Work. https://ec.europa. eu/info/sites/info/files/european-semester_thematic-factsheet_undeclaredwork_en.pdf.

12. European Commission. (2020). Eurostat. Harmonised unemployment rate by sex. https://ec.europa.eu/eurostat $/ \mathrm{tgm} /$ table.do? $\mathrm{tab}=$ table \&init $=1 \&$ language $=$ en $\&$ pcode $=$ teilm $020 \& p l u g$ in $=1$

13. European Commission. (2020). Eurostat. Newsrelease: Euroindicators 2020. https://ec.europa.eu/eurostat/ documents/2995521/10159296/3 30012020-AP-EN.pdf/b9a98100-6917c3ea-a544-ce288ac09675.

14. European Commission. (2020). Eurostat. Unemployment Statistics and Beyond. http://ec.europa.eu/eurostat/statistics-explained/index.php/ Unemployment_statistics_and_beyond.

15. European Commission. (2015). Report from the Commission to the 


\section{Journal of Contemporary Management Issues}

Council on the Functioning of the Transitional Arrangements on Free Movement of Workers from Croatia. COM/2015/0233 final. Brussels: European Commission.

16. Favell, A., Recchi, E. (2009). Pioneers of European Integration: Citizenship and Mobility in the EU. Cheltenham, UK.

17. Kahanec, P., Zimmermann, K. F. (2016). The free movement of workers in an Enlarged European Union: Institutional underpinnings of economic adjustment, Labor migration, EU enlargement, and the great recession. Berlin: Springer, 1-34.

18. Ministry of Interior Affairs of Slovak Republic. (2020). Statistical Overview of Legal and Illegal Migration in the Slovak Republic. https://www.minv.sk/ swift_data/source/policia/hranicna_a cudzinecka_policia/rocente-/ rok_2019/2019-rocenka-UHCP_EN.pdf

19. Mitze,T., Alecke, B. and G. Untiedt, 2012, A Panel VAR Approach for Internal Migration, Modelling and Regional Labor Market Dynamics in Germany, Empirical Modelling in Regional Science, Lecture Notes in Economics and Mathematical Systems 657, Berlin: Springer-Verlag.

20. National Council of the Slovak Republic. (2004). Act. No. 5/2004 Coll. https://www.zakonypreludi.sk/zz/2004-5

21. National Council of the Slovak Republic. (2011). Act No. 404/2011 Coll. https://ec.europa.eu/migrantintegration/librarydoc/slovakia-actno-404/2011-coll-on-stay-of-aliens

22. Palmer, J., R., B., Pytlíková, M., (2015). Labor market laws and IntraEuropean mobility: The role of the state in shaping destination choices. European Journal of Population, 31 (2), 127-153.
23. Partridge, M., D., Rickman D., S., (2003), The waxing and waning of regional economics: the chicken-egg question of jobs versus people, Journal of Urban Economics, 53,76-97.

24. Partridge, M., D., Rickman D., S., (2006). The Geography of American Poverty: Is There a Need for Placebased Policies? W E Upjohn Inst.

25. Pissarides, C., A., Wadsworth J., (1989). Unemployment and the interregional mobility of labour, Economic Journal, 99(397), 739-755.

26. Ritzen, J., (2017). A Second Chance for Europe: Economic, Political and Legal Perspectives of the European Union. Springer International Publishing.

27. Slovak Statistical Office. (2020). Labour Force Sample Survey results in the Slovak Republic for the 1st quarter 2019. https://slovak.statistics.sk

28. Trelová, S. (2017). Migration of workforce in the work market as a socio-economic result of globalization. In: Globalization and its socioeconomic consequences : part 6. Žilina: University of Žilina

29. Trend. (2018). Dochádzanie za prácou: Viac ako 2,5 eura denne na cestu Slováci dat' nechcú. : https://www. trend.sk/financie/dochadzanie-pracouviac-ako-2-5-eura-denne-cestu-slovacidat-nechcu

30. Ministry of Labour, Social Affairs and Family of the Slovak Republic-UPSVR (2020). Employment of Foreigners, March 2020. www.upsvr.sk.

31. Ministry of Labour, Social Affairs and Family of the Slovak Republic-UPSVR (2020). Unemployment in Slovakia by regions, March 2020. www.upsvr.sk.

32. Vagac, L., (2013), Internal Labour Mobility in Slovakia. Centre for Economic Development, Slovakia 


\section{MOBILNOST I MOGUĆNOSTI ZA RAD U EU I SLOVAČKOJ REPUBLICI}

Sažetak. Procesi globalizacije donose mobilnost i migraciju radne snage kao jednu od svojih karakteristika. Slobodno kretanje ljudi i radnika je jedno od prava građana Europske Unije (EU) te uključuje pravo na mobilnost, boravak $i$ zaposlenje u bilo kojoj članici EU-a, bez diskriminacije. Cilj ovog rada je analiza radne mobilnosti unutar EU-a, s posebnim naglaskom na Slovačku. Usvom povijesnom razvoju, Slovačka je pripadala zemljama, čije je stanovništvo uglavnom sesilo u strane države te nije predstavljala zemlju, koja bi primala doseljenike. Međutim, ona je postepeno postala država, u kojoj se zapošljavaju strani radnici, posebno u proizvodnim pogonima. Ovoj promjeni nije doprinijelo samo slovačko pristupanje EU-u, već posebno i gospodarski razvoj te stvaranje novih radnih mjesta, kako za domaće, tako i strane radnike. $U$ radu se analizira interna mobilnost $u$ Slovačkoj te se fokusira na analizu trendova zaposlenosti stranih radnika iz država-članica EUa, kao i izvan EU-a, između 2007. i 2019. godine. Za izradu rada, korišteni su podaci iz velikog broja značajnih izvora (izvješća Europske komisije, Eurostata, Međunarodne organizacije rada, Slovačkog statističkog ureda, koja se odnose na radnu mobilnost). U okviru istraživanja za stolom, prikupljene informacije su analizirane $i$ kritički procijenjene $s$ više perspektiva: kvantitativne, apsolutne, relativne i kros-sekcijske. Posebna se pozornost obraća analizi prateće dokumentacije. Značaj analizirane teme pojačava činjenica da je Slovačka trenutno primateljica strane radne snage, zbog nedovoljnih kvalifikacija domacih radnika. Stoga se uvode $i$ nove pravne mjere za ubrzavanja procesa zapošljavanja, uklanjanje administrativnih zapreka $i$ ubrzavanje procesa prilagodbe novim radnim uvjetima, u suradnji s poslodavcima, a što se posebno odnosi na radnike iz zemalja izvan EU-a. Nadalje, zapošljavanje radnika iz trećih zemalja u Slovačkoj je relativno zahtjevan $i$ dugotrajan proces. S jedne strane, zapošljavanje stranaca doprinosi ekonomskom razvoju, dok, s druge strane, ovaj proces potiče različite probleme, koji se uglavnom odnose na kulturnu i društvenu integraciju, što se ne može postići samo pravnom regulacijom.

Ključne riječi: mobilnost radne snage, migracije, zaposlenost, Europska Unija, tržište rada, Slovačka 